ANDRÊZA ARUSKA DE SOUZA SANTOS

DA ESTATIZAÇÃO À PRIVATIZAÇÃO: O CASO DAS TELECOMUNICAÇÕES NO BRASIL

Monografia apresentada ao Instituto de Ciência Política da Universidade de Brasília como requisito parcial para obtenção do grau de Bacharel em Ciência Política

Orientador: Prof. Antônio José E. Brussi

Brasília

2006 


\title{
DA ESTATIZAÇÃO À PRIVATIZAÇÃO: O CASO DAS TELECOMUNICAÇÕES NO BRASIL
}

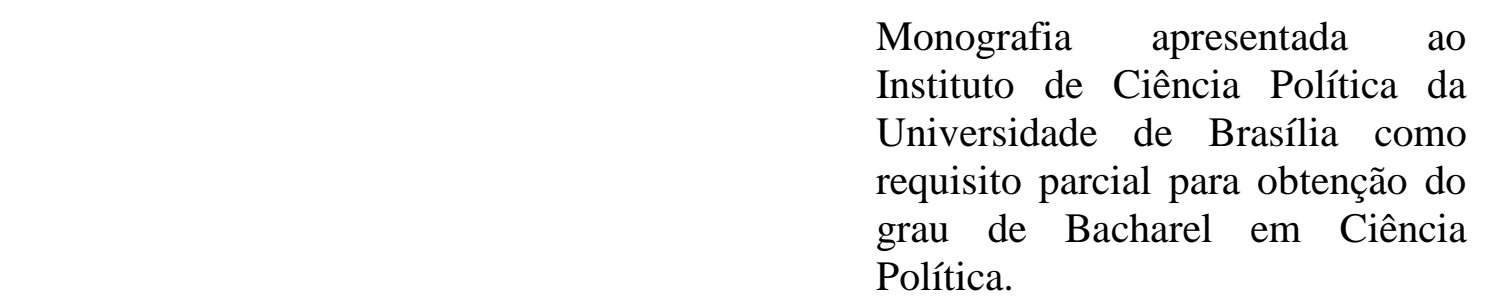

Aprovada em I

\section{BANCA EXAMINADORA}

Prof. Antônio José E. Brussi (ORIENTADOR)

Universidade de Brasília

\author{
Prof. João Paulo M.Peixoto \\ Universidade de Brasília
}

Prof. Juarez de Souza

Universidade de Brasília 


\section{Agradecimentos}

Em primeiro lugar, dedico o conhecimento adquirido e cada uma destas páginas a Deus "porque o SENHOR dá a sabedoria, e da sua boca vem a inteligência e o entendimento." (Pv. 2:6).

À minha família, agradeço a todo suporte que me foi dado. O carinho, amor, paciência e alegria de cada um fez com que essa conquista recheasse o meu coração e a minha memória das mais doces lembranças.

Aos meus amigos de curso, que faço questão de nomear alguns, Ana Carol, Carol, Cecília, Sabrina e Thiago, agradeço pela ajuda, pela amizade e pelas sugestões. À Carol, em especial, agradeço pela companhia de tantas horas na biblioteca, o que demonstrou uma verdadeira disposição e fez com que momentos de estudo se tornassem tão divertidos.

Aos professores e funcionários do Instituto, agradeço de coração. Cada aula e cada texto compartilhado serviram de inspiração e de norte para que eu pudesse chegar ao final do curso com a certeza de que fiz a escolha certa e de que o estudo em Ciência Política é de fato uma busca incessante e também incansável pela paixão que desperta.

Dedico este último parágrafo ao meu orientador. Suas palavras, sua leitura minuciosa, suas sugestões bibliográficas e, muito mais do que isso, sua amizade e atenção fizeram com que meus momentos de angústia na produção deste trabalho se suavizassem transformando-se em confiança e entusiasmo! 


\section{Sumário}

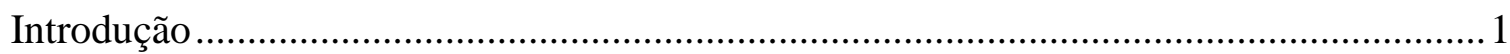

1. Modelo e Crise do Estado Nacional Desenvolvimentista ...............................................5

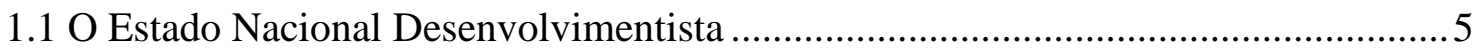

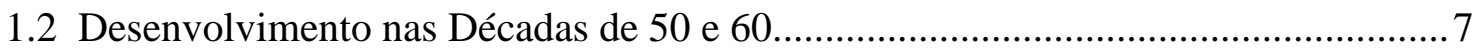

1.3 Desenvolvimento Econômico Brasileiro na Crise Democrática ............................... 9

1.4 A Década de 80, Dilema: Inflação e Recessão........................................................ 11

1.5 Reformas Econômicas nos Governos de Collor e Itamar:.......................................... 17

1.6 Reformas Econômicas no Governo Itamar............................................................20

1.7 Reformas Econômicas no Primeiro Governo FHC …..............................................2 21

2. Privatização das Telecomunicações: Contexto, Capacidade e Interesse do Estado

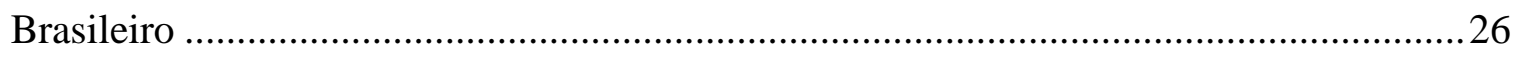

2.1 Breve Histórico das Telecomunicações no Brasil ...................................................26

2.2 Modelo Intervencionista das Telecomunicações no Brasil .....................................28

2.3 Endividamento e Esgotamento do Modelo Estatal...................................................30

2.4 Privatização das Telecomunicações: Atuação do Congresso Nacional e Instrumentos

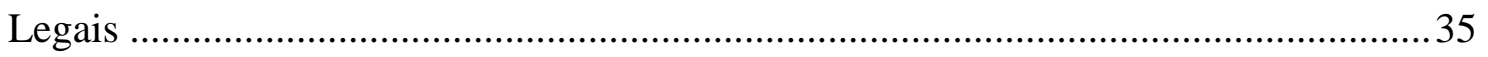

2.5 O Novo Modelo Adotado: A Quem Serviu? ...........................................................43

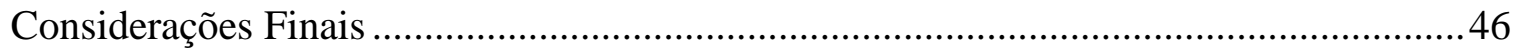

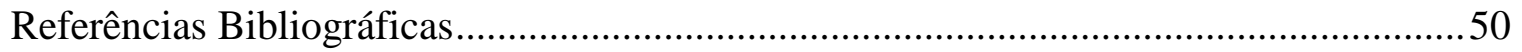

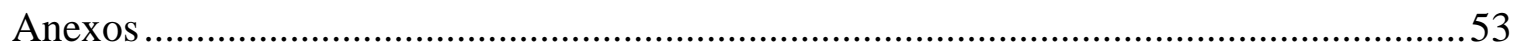




\section{Lista de Tabelas}

Tabela 1: Posicionamento dos principais Partidos Políticos quanto ao monopólio estatal

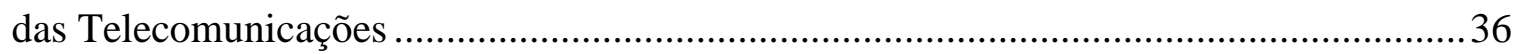

Tabela 2: Resultado da votação da PEC 03/95 na Câmara.................................................37

Tabela 3: Posicionamento Partidário no Primeiro Turno de votação da Câmara................38

Tabela 4: Posicionamento Partidário no Segundo Turno de votação da Câmara...............39

Tabela 5: Resultado da votação da PEC 03/95 do Senado ...............................................4

Tabela 6: Posicionamento Partidário no Primeiro Turno de votação do Senado ...............41

Tabela 7: Posicionamento Partidário no Segundo Turno de votação do Senado ...............42 


\section{Lista de Siglas}

CAD - Conselho Nacional de Desestatização

Contel - Conselho Nacional de Telecomunicações

Embratel - Empresa Brasileira de Telecomunicações

FMI - Fundo Monetário Internacional

FNT - Fundo Nacional de Telecomunicações

LGT - Lei Geral das Telecomunicações

PC do B - Partido Comunista do Brasil

PDT - Partido Democrático Trabalhista

PFL - Partido da Frente Liberal

PL - Partido Liberal

PMDB - Partido do Movimento Democrático Brasileiro

PMN - Partido da Mobilização Nacional

PND - Programa Nacional de Desestatização

PP - Partido Progressista

PPR - Partido Progressista Reformador

PPS - Partido Popular Socialista

PSB - Partido Socialista Brasileiro

PSC - Partido Social Cristão

PSD - Partido Social Democrático

PSDB - Partido da Social Democracia Brasileira

PT - Partido dos Trabalhadores

PTB - Partido Trabalhista Brasileiro

PV - Partido Verde 
SNT - Sistema Nacional de Telecomunicações 


\title{
Introdução
}

A discussão sobre os limites e a atuação do Estado na esfera econômica é parte de uma agenda constante nos estudo de Ciência Política. Sua relevância aumenta significativamente com a crescente centralidade de estudos sobre reforma do Estado. A esse respeito o trecho abaixo traz uma oportuna contribuição:

\begin{abstract}
A agenda de reformas insere-se no rol das questões de Estado, e não no mero interesse partidário ou mesmo na transitoriedade de um determinado governo, independentemente de sua matriz ideológica. Reformar o Estado brasileiro tem sido tarefa permanente (Estado) e não transitória (Governo), para usar uma das distinções clássicas da Ciência Política entre Estado e Governo. (PEIXOTO, 2003, p. 8).
\end{abstract}

A fim de conhecer mais sobre esse vasto campo de estudo, a presente monografia pretende, em seu exercício de função formativa na pesquisa à qual se insere, trazer à tona o tema sobre o papel do Estado brasileiro na esfera econômica. É importante salientar que dado a abrangência e a importância da discussão sobre o assunto para os estudos contemporâneos de Ciência Política, o objeto em análise se restringirá ao exame das mudanças recentes da intervenção estatal no campo econômico e o enfoque acolhido diz respeito ao processo de privatização das telecomunicações no Brasil. A escolha da delimitação do escopo da análise tem por finalidade entender o processo de privatização das telecomunicações no Brasil no que diz respeito ao contexto político externo e interno, além de analisar a forma de atuação do setor e os interesses do Estado brasileiro nele envolvidos. Esta delimitação da investigação no campo das telecomunicações se deu a partir da constatação de que este setor era tradicionalmente monopolizado pelo Estado, não somente no Brasil como em vários países do mundo. Dessa forma, entender o motivo da adoção do modelo de desestatização, gerado a partir da concepção da necessidade de 
um Estado menos intervencionista, representa um importante foco de investigação no exercício de buscar sua melhor compreensão.

O presente trabalho, no primeiro momento, trará uma breve análise histórica da atuação do Estado brasileiro no setor econômico desde 1930 até 1998, final do primeiro governo Fernando Henrique Cardoso (FHC). A consolidação da sociedade urbano industrial brasileira, que se inicia a partir dos anos 1930 e que teve como marco uma maior participação do Estado no plano econômico e social fez com que esse período se tornasse o ponto inicial do estudo. As reformas que ocorreram posteriormente com momentos de maior e menor intervenção estatal, bem como os acontecimentos no cenário internacional serão da mesma forma colocados para que o Capítulo possa viabilizar uma melhor compreensão do contexto e atuação do Estado brasileiro no momento em que este inicia suas reformas de desnacionalização e desregulamentação de suas empresas, ocorridas a partir do Programa Nacional de Desestatização (PND) do governo Fernando Collor e posteriormente ampliado no governo FHC.

No segundo momento, o estudo se aprofundará na questão das telecomunicações no Brasil. Primeiramente, buscou-se mostrar como o setor se desenvolveu desde a criação e instalação dos primeiros telefones no país. A abordagem nesse ponto é descritiva e mostrará, de maneira bastante sucinta, os modelos de exploração da telefonia no país, que passaram por uma fase de concessão a inúmeras empresas até chegarem, nos anos 1960, a um cenário de extrema desintegração, quando então muda-se para o modelo estatal.

A análise do período em que as telecomunicações estiveram sob o controle estatal será um pouco mais aprofundada, a fim de explorar a motivação do Estado em monopolizar o setor e os motivos que levaram à sua posterior privatização. A privatização das telecomunicações, por sua vez, será mostrada dentro do contexto de desestatização, a partir das mudanças da forma de atuação do Estado na vida econômica do país, abordando 
conceitos sobre a tendência mundial de flexibilização de monopólios e a atuação e os limites do Estado, bem como de seus instrumentos legais, que culminaram com a privatização de setores essenciais da economia, como é o caso das telecomunicações.

Finalmente, nas considerações finais pretende-se enfatizar a importância do posicionamento político-ideológico na escolha do perfil a ser adotado pelo Estado no que se refere à intervenção econômica e, por outro lado, demonstrar que a conjuntura da política externa e internacional também são fatores importantes nessa escolha. Pretende-se mostrar que o reconhecimento de fatores conjunturais e econômicos não esgotam os instrumentos e posicionamentos políticos possíveis.

Faz-se necessário enfatizar que o perfil da análise é estritamente político, ou seja, a preocupação central se concentra na compreensão do cenário político interno e da conjuntura externa que culminaram (associado a outros fatores) na decisão de quebrar o monopólio das telecomunicações. Dessa forma, dados econômicos e aspectos técnicos concernentes a fornecedores e usuários de serviços de telefonia serão desconsiderados para efeito de análise.

Para orientar o estudo algumas questões centrais são levantadas. Respondê-las, contudo, consiste em um desafio. Ainda assim a investigação pretende responder satisfatoriamente aos seguintes questionamentos:

- Quais foram as principais razões no contexto político que levaram a uma mudança no perfil do Estado nacional desenvolvimentista para um modelo menos intervencionista?

- Como é possível compreender melhor o "esgotamento" das telecomunicações no que diz respeito aos interesses e instrumentos políticos?

A metodologia utilizada para o presente objeto de estudo se classifica em uma pesquisa empírica, ou seja, tem como objeto uma realidade determinada. No caso, a pesquisa versa sobre o Brasil e seu processo de desregulamentação. 
Dentro dessa análise empírica optou-se por um estudo de caso contextualizado, em que se propôs estudar de forma mais detalhada a privatização das telecomunicações dentro de suas variáveis e determinantes políticos.

A pesquisa se insere em um contexto bibliográfico pertinente que a vincula a um processo de desenvolvimento na pesquisa em Ciência Política. Sobre esse aspecto, cabe ressaltar que foram utilizados autores conhecidos do estudo contemporâneo de política, alguns deles tratam de questões práticas da teoria política contemporânea como a questão da crise fiscal do Estado, outros tratam de questões como: a reforma do Estado, globalização e privatização.

A base deste trabalho se constitui de uma revisão bibliográfica nos moldes que foi exposto no parágrafo anterior, utilizando também, de maneira extensiva, artigos de revistas especializadas em Ciência Política e também publicações de órgão públicos do período em estudo. A análise e coleta de dados primários também se fizeram presentes. Nesse ponto, pode-se citar: consulta aos discursos dos presidentes brasileiros no período estudado; consulta a leis e decretos aprovados concernentes à questão em análise; verificação das listas de votação no Congresso Nacional da proposta de emenda Constituição que quebrou o monopólio estatal das telecomunicações e, finalmente, consulta às Constituições Nacionais do período relacionado. 


\section{Modelo e Crise do Estado Nacional Desenvolvimentista}

\subsection{O Estado Nacional Desenvolvimentista}

Durante a década de 1930, ocorreram várias transformações no Estado Brasileiro. Foi a partir desse período que deixou de existir o Estado oligárquico no Brasil e a estrutura político - administrativa começou a ser organizada segundo um modelo burocrático. Também foi nessa época que o setor industrial adquiriu maior importância e medidas econômicas assinalaram o protecionismo da incipiente indústria brasileira. (IANNI, 1979, p. 4).

A transição do Estado do tipo oligárquico com base agrícola, predominante até 1930, para o Estado do tipo burguês, em que o setor industrial passou a predominar, correspondeu a uma verdadeira revolução na economia brasileira. O Estado desempenhou novos e decisivos papéis e houve uma série de recomendações e reajustes econômicos, sociais, políticos e culturais.

No primeiro governo de Getúlio Vargas (1930-45), o Estado desempenhou várias funções decisivas para o funcionamento e expansão econômica. Rubem Barbosa Filho (1996, p. 23) sintetiza bem a importância que teve o Estado brasileiro para o desenvolvimento econômico nesse período;

\footnotetext{
Vargas organiza um processo de criação do mundo urbano e industrial no País, reforçando o papel do Estado enquanto fac totum das condições básicas para o dinamismo econômico. É dele o controle sobre a movimentação de capital, é dele a responsabilidade pela construção da infra-estrutura necessária ao desenvolvimento da atividade econômica, é dele a proteção ao capital nacional, é dele a função de criar e disciplinar seres adequados à viabilização do processo de industrialização e modernização econômica e é dele, ainda, o privilégio de representar a nação enquanto personagem autônoma e independente no cenário internacional.
} 
Verifica-se, na fase que se estende de 1930 a 1945, que o poder Executivo teve notável importância no campo da política econômica. A este respeito, Octávio Ianni (1979, p. 7) afirma que:

Em geral, o Executivo dispunha de bases constitucionais, recursos financeiros, condições organizatórias e pessoal especializado para atuar. Assim, ele podia modificar ou propor novos objetivos, diretrizes, técnicas e órgãos relativos às relações e estruturas econômicas do País.

O contexto internacional ajuda a entender o novo papel intervencionista que o Estado passa a assumir no Brasil com Getúlio Vargas pois as crises econômicas em geral criam condições a partir das quais o Estado é levado a desempenhar papéis mais ativos na economia. No Brasil, por exemplo, a história da economia cafeeira mostra como diferentes governos adotaram medidas de proteção e incentivo a fim de resguardar os interesses dos comerciantes e produtores de café. Quando há a combinação de crise política com crise econômica, como no caso da Depressão Econômica Mundial de 1929 e também da Segunda Guerra Mundial, o poder público ganha maior autonomia para intervir e estimular novas atividades produtivas. No Brasil, a partir de 1929, a ideologia do liberalismo econômico perdeu prestígio com as condenações que as crises, os intelectuais e as instituições políticas trouxeram, levando a um cenário que favoreceu um modelo de monopólio estatal em vários setores da economia, como o setor siderúrgico, maior exemplo da época. (CALDAS e PEIXOTO, 2001, p. 32).

É verdade que algumas medidas protecionistas já eram adotadas por governantes brasileiros anteriores a Vargas. Entretanto, o poder público passou a participar de modo mais amplo e sistemático na economia do país após 1930. Esse fato pode ser observado nas Constituições Brasileiras, que em 1891 e na reforma de 1926 foram bastante 
influenciadas pela doutrina liberal, enquanto que, em 1934, adotou-se explicitamente princípios nacionalistas e intervencionistas. E na Constituição de 1937 o texto foi ainda mais explícito ao enunciar a possibilidade de atuação do poder público em qualquer esfera da economia. (Constituições Brasileiras, 1999/2000).

Essa fase intervencionista da economia brasileira não se encerra ao final do primeiro Governo Vargas - 1945, como demonstra Octávio Ianni (1979, p. 57).

O término da guerra e a chamada redemocratização do país estavam incluindo novos problemas e novos grupos sociais no debate relativo às estratégias políticas de desenvolvimento. Além disso, as próprias tarefas práticas do poder público exigiam decisões imediatas e, às vezes, inovadoras. E a experiência já acumulada, no campo das relações entre o poder público e as atividades econômicas, demonstrara a conveniência de maior coordenação da política econômica governamental.

O fato é que o país estava convencido - após as crises da exportação de produtos primários (café, borracha, açúcar, entre outros) e as crises econômicas mundiais - de que havia muitas limitações e insegurança na dependência externa de uma economia exportadora. O nacionalismo econômico tornou-se a manifestação da idéia de desenvolvimento, de industrialização e de independência. Estava em gestação a experiência do então chamado capitalismo nacional.

\subsection{Desenvolvimento nas Décadas de 50 e 60}

A política econômica estatizante e de liderança e controle do poder público brasileiro nas decisões nesse setor foi uma tendência dominante nos anos da Segunda Guerra Mundial. A continuidade dessa tendência para os anos seguintes já estava tecnicamente 
preparada, dada as condições favoráveis de realização de mais uma etapa no desenvolvimento econômico do Brasil. (IANNI, 1979, p. 89).

Os anos de 1951-54 e 1961-64 foram mais notáveis no envolvimento do poder público nas atividades do sistema econômico e financeiro do país. Entretanto, é possível dizer que as mudanças na sociedade brasileira, no sentido desta tornar-se mais urbana e menos rural, foram notáveis em todo o período que se estende após 1930. (IANNI, 1979, p. 307).

O Governo Dutra (1946-50) se diferenciou por reduzir as funções econômicas do poder público e também por pouco se envolver com o desenvolvimento econômico e industrial do país. Assim, as diretrizes econômicas adotadas durante seu Governo corresponderam a uma ruptura da orientação predominante nos anos anteriores. O liberalismo econômico foi colocado numa posição mais ativa, contrastando com a intervenção estatal adotada nos anos da Segunda Guerra Mundial. (IANNI, 1973, p. 93).

Logo em seguida, nos anos 1951-54, novamente com Vargas no poder, abandonaramse as diretrizes inspiradas pela doutrina liberal com o intuito de resolver os problemas econômicos e financeiros mais urgentes do país e em favor do desenvolvimento industrial acelerado. O poder público tornara-se assim mais indispensável e decisivo para a economia brasileira. (IANNI, 1979, p. 123).

Nos anos do Governo Kubitscheck (1956-60) realizou-se uma ampla e profunda transformação do sistema econômico do país. A política econômica desses anos foi sistematizada sob o "Programa de Metas". (IANNI, 1979, p. 151).

Nesse período, a atuação do Governo na economia operou de modo a acelerar o desenvolvimento econômico brasileiro, em especial, promovendo a industrialização a partir do apoio do setor privado nacional e estrangeiro. Octávio Ianni (1979, p.160) caracteriza a política econômica adotada nessa fase como um sistema capitalista associado, com uma combinação com as tendências do sistema capitalista mundial: 
Assim, o que distinguiria as políticas econômicas dos Governos Getúlio Vargas (51-54) e Juscelino Kubitschek de Oliveira (56-60) seria o seguinte: teria havido uma transição (casual ou deliberada, conforme o nível em que se desenvolve a análise) de uma política destinada a criar um sistema capitalista nacional para uma política orientada para o desenvolvimento econômico dependente ou associado. Em forma breve, pode-se dizer que o Programa de Metas visava transformar a estrutura econômica do País, pela criação da indústria de base e reformulação das condições reais de interdependência com o capitalismo mundial.

Nos anos de JK a economia brasileira experimentou um novo processo de internacionalização da economia. A estrutura do setor industrial tornou-se amplamente integrada à estrutura econômica mundial. Essa opção política fortaleceu o setor privado,

principalmente as empresas ligadas a grupos estrangeiros e as empresas multinacionais. É possível ainda dizer que a idéia de industrialização e desenvolvimento dissociada da idéia de autonomia seguiu-se nos anos posteriores. (IANNI, 1979, p. 160).

\title{
1.3 Desenvolvimento Econômico Brasileiro na Crise Democrática
}

Nos anos de 1961-64 houve uma crise geral da economia e da política brasileira. Sobre o período, Octávio Ianni (1979, p. 196) fala que:

\begin{abstract}
Pode-se afirmar que os Governos de Jânio Quadros e João Goulart não estavam em condições de resolver as contradições herdadas do Governo Kubitscheck. Já não havia mais condições políticas e econômicas para a conciliação entre ideologia nacionalista e capitalismo nacional [...], além disso, as contradições entre as classes sociais tanto na cidade como no campo, haviam-se aguçado.
\end{abstract}

O resultado dessa situação foi a deflagração do golpe militar de 1964 que interrompeu a experiência democrática nacional inaugurando um novo e longo período da política brasileira que só se encerra em meados da década de 1980. 
Os governos do regime autoritário (1964-85) adotaram medidas econômicas que, em linhas gerais, guardavam um aspecto semelhante entre si e entre os governos anteriores, no que concerne à intervenção estatal em alguns setores do sistema econômico nacional, com responsabilidades na construção da infra-estrutura econômica e social. Entretanto, a política econômica do período não visou à estatização econômica, ao contrário, continuou a receber capital e tecnologia estrangeira na busca por atingir um equilíbrio entre governo, setor privado, empresa nacional e empresa estrangeira.

Os governos de Castello Branco, Costa e Silva, Garrastazu Médici, Ernesto Geisel e João Figueiredo não pretenderam modificar as estruturas sociais existentes no país. Em geral, buscava-se assegurar a viabilidade e a prosperidade do sistema econômico. Segundo Ianni, "Não se tratava de 'estatizar a economia' ou criar o 'capitalismo de Estado'. Tratava-se apenas e simplesmente, de aperfeiçoar o status quo". (IANNI, 1979, p. 256).

O período militar teve uma tendência internacionalista, em que as empresas estrangeiras ocuparam uma posição privilegiada. Entretanto, as relações de interdependência e complementaridade não impediram que também se desenvolvessem diretrizes de tipo nacionalista a fim de eliminar pontos de estrangulamento da economia brasileira, com uma política de substituição de importações, com ênfase para os insumos básicos.

Além da ênfase dada no período aos insumos básicos, a preocupação recorrente das forças armadas com a temática da segurança nacional e do desenvolvimento estratégico proporcionou que o Poder Executivo adotasse medidas fundamentais que estruturaram as bases institucionais das telecomunicações no Brasil, iniciando a estatização do setor, o que constituiu uma grande mudança na forma como o sistema até então operava.

No caso das telecomunicações, outros fatores podem ser citados como estimuladores à formação do monopólio público no setor, como: o intenso crescimento econômico que o 
período trouxe consigo, o fomento à industrialização, a expansão do mercado interno e o fim do isolamento de diversas regiões brasileiras ${ }^{1}$. (CRUZ, 2002, p. 26).

\subsection{A Década de 80, Dilema: Inflação e Recessão}

A política de planejamento e criação das empresas estatais, que teve lugar entre a década de 1930 até a primeira metade dos anos 1970 foi, em muitos casos, uma opção política justificada por fatores como: segurança nacional, desenvolvimento econômico, soberania nacional e autonomia política e econômica. Todavia, esses argumentos foram, gradualmente, substituídos, conforme diminuíam os recursos e os interesses para o financiamento das empresas estatais, além do aumento do prestígio da iniciativa privada e do cenário de valorização da internacionalização econômica.

A década de 1980 acentuou no Brasil a discussão sobre a continuidade da intervenção do Estado na economia. Outros países já estavam adiantados no processo de retirada e redefinição da intervenção estatal no campo econômico, como o Chile, sob a ditadura de Pinochet; a Inglaterra, de Margareth Tatcher e os Estados Unidos, no Governo de Ronald Reagan.

A estratégia básica para o desenvolvimento defendida nos anos 1980 pelo Fundo Monetário Internacional (FMI), pelo Banco Mundial, e pelo Consenso de Washington (1989), envolvia minimizar o papel do Estado, mediante a privatização de empresas de propriedade estatal e a eliminação das regulamentações e intervenções governamentais na economia. O Governo seria responsável apenas pela macroestabilidade.

\footnotetext{
${ }^{1}$ A estatização e privatização das telecomunicações no Brasil é o tema principal que será abordado no capítulo seguinte.
} 
É importante enfatizar que a convergência observada a partir dos anos 1980 em direção a políticas econômicas que enfatizam o sistema de mercado não teve a mesma origem. Na Europa Ocidental e nos Estados Unidos houve uma reação ao excesso de intervenção do Estado na economia, no primeiro caso, e à expansão dos sistemas de previdência social, no segundo. Já o Leste Europeu se rendeu à livre-iniciativa para atenuar a crônica estagnação em que se encontravam os países socialistas. Na América Latina, a reação ao "inchamento" do Estado decorreu do excesso de endividamento do segmento empresarial estatal. (LONGO, 1993, p. 69).

O livro Chutando a Escada (CHANG, 2002) explica um processo que geralmente ocorre nos países em desenvolvimento. Segundo o autor, o desenvolvimento que ocorre nesses países tem sido estimulado segundo uma agenda de "boas políticas" que os países desenvolvidos projetaram. Essa prescrição é feita por instituições como o Consenso de Washington (acima citado) que defende, em linhas gerais, a liberalização do comércio internacional e dos investimentos, políticas de privatização e desregulamentação. Além disso, essa prescrição também defende as instituições democráticas, um judiciário independente, a proteção dos direitos de propriedade privada e uma governança empresarial orientada para o mercado.

É fato que os resultados econômicos alcançados por meio da política de privatizações não é a questão central deste trabalho, mas a análise não pode desconsiderar a influencia da ascensão do neoliberalismo e das pressões externas na adoção de tal política, e neste ponto convém ressaltar que os países desenvolvidos não acataram o alerta já feito por Friederich List, citado por Brussi (1988, p. 1), que dizia que o livre comércio é mais benéfico entre países de semelhante nível industrial.

Segundo Brussi "o livre comércio internacional não pode alcançar o objetivo de difundir a riqueza e o progresso de maneira equilibrada e igualitária através do mundo 
devido aos níveis de produtividade altamente desiguais". (BRUSSI, 1988, p. 1). Mesmo assim, houve uma forte tendência à uma abertura internacional com argumentos internos de se buscar uma maior vantagem competitiva e, externamente, a abertura significaria uma maior e melhor inserção do país na produção mundial.

Ainda sobre esse ponto, convém ressaltar um estudo comparativo de Flávio da Cunha Rezende (2000, p. 138) entre os países desenvolvidos e os países em desenvolvimento quanto às mudanças recentes no papel econômico do Estado nacional. O resultado de seu estudo leva à compreensão de que muitas das políticas e instituições que os países desenvolvidos recomendam aos países em desenvolvimento não são as mesmas que eles freqüentemente utilizam. Essa conclusão vai ao encontro daquela feita por Chang (2003, p.207), que mostra que as políticas e instituições utilizadas pelos países altamente desenvolvidos, nos estágios iniciais de desenvolvimento, diferem significativamente daquelas que eles freqüentemente exigem que sejam implementadas nos países em desenvolvimento.

Sobre a desregulamentação econômica, Joseph Stiglitz (2003, p. 112) aponta, no trecho abaixo, que a demanda de desregulamentação existia há muito tempo e por razões distintas:

A demanda de desregulamentação existia há muito tempo. Quando feita de maneira correta, a regulamentação ajuda a garantir que os mercados funcionem competitivamente. Há sempre algumas empresas que querem tirar vantagem de sua posição dominante. Idealmente, a regulamentação impede que as empresas tirem vantagem de seu poder de monopólio quando a competição é limitada porque há um 'monopólio natural', um mercado no qual haveria naturalmente uma ou duas empresas, mesmo que nada se faça para bloquear a entrada ou eliminar os concorrentes. As regulamentações ajudam a conter os conflitos de interesses e as práticas abusivas, de modo que os investidores possam estar confiantes em que o mercado propicia um jogo de iguais e que aqueles que deveriam defender seus interesses realmente o fazem. Mas o lado reverso de tudo isso é que a regulamentação restringe os lucros e, assim, a desregulamentação significa mais lucros. E, nos anos 90, aqueles que percebiam os lucros maiores que a desregulamentação traria estavam dispostos a investir para obtê-los. 
No Brasil, foi, principalmente, durante os anos de 1980 e 1990 que houve inúmeras crises econômicas e de descapitalização e um intenso processo de desregulamentação econômica. Esse processo ganhou mais força com a aceleração do processo de globalização e o fim da Guerra Fria. O consenso negativo a respeito do Estado, que ocorria em muitos países latino-americanos, era mais uma reação aos baixos níveis de prestação de serviços públicos e à corrupção, do que uma negação da importância do Estado para a sociedade. (CALDAS e PEIXOTO 2001, p. 143).

Além do contexto internacional, a década de 1980 trouxe consigo, apenas entre 198189, a implementação de sete planos de estabilização econômica, sendo que todos fracassaram. Isso, associado à incapacidade de financiar investimentos, fez com que vários setores do país questionassem a doutrina do nacional desenvolvimentismo. A maior crítica era de que o desenvolvimentismo econômico era sustentado por crônicos déficits orçamentários. A atuação do Estado na economia começava a ter sua forma e continuidade discutida. As políticas intervencionistas foram culpadas pelos déficits e fracassos econômicos do país e as alternativas propostas levavam a uma redução do papel do Estado. (LONGO, 1993, p.27).

No Governo Figueiredo (1979-84), o Brasil iniciou, timidamente, a retirada do Estado da economia, falava-se em abertura política e redefinição da intervenção estatal no campo econômico, atendendo, sobretudo, aos anseios manifestados pelas lideranças empresariais paulistas. A tese dos que defendiam a desestatização era de que o Estado tornara-se lento e pesado, que era ineficiente e atrapalhava o livre financiamento dos mercados. Com isso, em um ambiente inflacionário e sem perspectivas de investimentos, o argumento de que o Estado era essencial ao crescimento da economia encerrava-se e a desregulamentação e reestruturação das fronteiras de intervenção do Estado ganhavam espaço. 
Sobre o Governo Figueiredo, convém ressaltar o trecho de Marcos Jordão Teixeira do Amaral Filho (1996, p.43).

No Brasil mergulhado em profunda crise, começou-se a empregar o termo desestatização para reivindicar a redução do papel do Estado na atividade econômica. O Governo Figueiredo, sob diversos aspectos bastante vacilantes, encampou a idéia, mas não teve competência e objetivas condições políticas para efetivar esse projeto. E a despeito dos esforços do então ministro Hélio Beltrão, burocrata de carreira alçado à condição de ministro da desburocratização, o mandato presidencial encerrou-se com um balanço bem negativo.

O Governo Figueiredo limitou a sua ação no que diz respeito às privatizações, ou seja, ainda caberia ao Estado participar da criação da infra-estrutura nacional e evitar que setores estratégicos da economia nacional fossem entregues a empresas estrangeiras.

O Governo Sarney (1985-89), de forma geral, manteve a mesma linha de seu antecessor no que diz respeito à desestatização. Houve, todavia, um avanço significativo na discussão da matéria, embora não tenha conseguido êxito na realização de um programa de privatização.

Mesmo porque, do ponto de vista econômico, o governo Sarney foi bastante conturbado por ter apresentado planos econômicos ineficazes para combater a inflação e estabilizar a economia. Ainda assim, pode-se ressaltar que, no plano externo, Sarney desenvolveu uma política de manter o mercado doméstico fechado para a concorrência estrangeira, principalmente em alguns setores, como a informática. (http//vejaonline.abril.com.br).

A herança deixada para a década de 90 era de que o Estado deveria iniciar a abertura comercial e financeira ao capital estrangeiro e os históricos monopólios estatais deveriam ser privatizados, como nos fala Juarez de Souza (2003, p.1). 
O Estado deixaria à iniciativa privada a produção de bens e serviços, bem como a liderança do processo de desenvolvimento econômico e se tornaria, fundamentalmente, regulador das concessões de serviços públicos, mediante a criação de agências reguladoras especializadas, e provedor subsidiário de funções públicas clássicas como educação para os desafortunados, saúde pública, administração da justiça e segurança.

Em tempo, cabe ressaltar a questão da crise fiscal do Estado, explorada por James O’Connor (1977). A tese consiste no fato de que uma das premissas básicas do Estado Capitalista é o desempenho de duas funções: acumulação e legitimação, ou seja, o Estado deve manter ou criar condições que viabilizem uma lucrativa acumulação de capital. Por outro lado, e muitas vezes de forma contraditória, deve manter e criar condições para uma harmonia social.

A questão da contraditoriedade é colocada porque o Estado acaba assumindo duas despesas - Capital Social: despesa exigida para a acumulação lucrativa; e Despesa Social: projetos e serviços exigidos para a manutenção da harmonia social. Ocorre que, a acumulação das Despesas de Capital e Despesa Social cria tendências para crises econômicas, sociais e políticas, pois, as despesas públicas tenderiam a aumentar mais rápido do que o meio de financiá-las.

O autor aponta três formas para o Estado financiar os crescentes gastos orçamentários; a saber: criação de empresas estatais produtoras de excedentes que, por sua vez, podem ser usados para cobrir as Despesas de Capital e a Despesa Social; emissão de títulos e tomada de empréstimos por conta de futuras receitas fiscais e, por fim, elevação e criação de impostos.

Conquanto o autor tenha escrito a obra baseando-se exclusivamente em dados da economia norte-americana, verifica-se a oportunidade do texto para a discussão deste capítulo, pois, a crise econômica em que se encontrava o Estado brasileiro ao final da década de 1980 teve como uma de suas principais justificativas, por parte dos 
governantes, o aumento das despesas públicas, e esse aumento, por seu turno, era tido como conseqüência das despesas que as empresas estatais demandavam. Diferente do que o autor coloca, as empresas estatais não eram mais apontadas como forma de gerar excedentes para cobrir os gastos com Despesa de Capital e Despesa Social.

Dessa forma, a doutrina do liberalismo do início do Século XX e sua política econômica que subestimava a intervenção e o controle estatal, que já houvera perdido espaço pela incapacidade de responder às distorções do capitalismo no final dos anos 20, voltava ao cenário econômico após as dificuldades da indústria e da economia, além das novas mudanças no contexto internacional.

\subsection{Reformas Econômicas nos Governos de Collor e Itamar:}

Conhecem Vossas Excelências a agenda de medidas básicas com que encetarei nossa estratégia de extermínio da praga inflacionária. Não poderemos edificar a estabilização financeira sem sanear, antes de tudo, as finanças do Estado. É imperativo equilibrar o orçamento federal, o que supõe reduzir drasticamente os gastos públicos. Para atingir o equilíbrio orçamentário, é preciso adequar o tamanho da máquina estatal à verdade da receita. Mas isso não basta. É preciso, sobretudo, acabar com a concessão de benefícios, com a definição de privilégios que, independente de seu mérito, são incompatíveis com a receita do Estado. No momento em que lograrmos esse equilíbrio - o que ocorrerá com certeza - teremos dado um passo gigantesco na luta contra a inflação, dispensando o frenesi das emissões e controlando o lançamento de títulos da dívida pública. [...]

Meu pensamento, neste ponto, é muito simples. Creio que compete primordialmente à livre iniciativa não ao Estado - criar riqueza e dinamizar a economia.

Entendo assim o Estado não como produtor, mas como promotor do bem estar coletivo. Daí a convicção de que a economia de mercado é forma comprovadamente superior de geração de riqueza, de desenvolvimento intensivo e sustentado. Daí a certeza de que, no plano internacional, são as economias abertas as mais eficientes e competitivas.[...]

Em síntese, essa proposta de modernização econômica pela privatização e abertura é a esperança de completar a liberdade política, reconquistada com a transição democrática, com a mais ampla e efetiva liberdade econômica. (COLLOR, 1990, discurso de posse).

Essa discussão sobre reforma do Estado, associada a uma meta de redução do seu tamanho, redução ao escopo de suas atividades e à natureza de sua intervenção, ganhou mais força e forma quando se iniciou o Governo Collor. 
Após assumir o Governo, em 1990, Collor apresentou à sociedade o documento: "Brasil: Um Projeto de Reconstrução Nacional”. O Projetão, como ficou conhecido, tinha como meta tornar o país moderno e com condições de melhorar a qualidade de vida da sociedade. Um dos aspectos de modernidade a ser implantado era a reforma do Estado, que deveria dedicar-se às funções essenciais na área de saúde, educação e infra-estrutura e liberar a economia para que o mercado pudesse ser recomposto e tornar possível que a competitividade empresarial alcançasse níveis internacionais abrindo assim a economia ao mundo.

A justificativa para essa proposta apoiava-se na consideração da década de 1980 como uma década perdida, onde o Estado funcionava mal e as empresas perderam competitividade. A proposta considerava que no país havia a defrontação de graves problemas estruturais e estagnação econômica, fruto não de um processo conjuntural, mas do esgotamento do próprio padrão de desenvolvimento adotado nos últimos 50 anos e tudo isso associado à reorganização do mercado internacional. Dessa forma, era necessário um Estado mais ágil e bem informado. (COLLOR, 1991, prefácio).

O Programa previa a desregulamentação de setores da atividade econômica fortalecendo o papel fiscalizador do Estado. O Programa Nacional de Desestatização (PND) fruto da Lei 8.031, de 12 de abril de 1990, era o instrumento para, inicialmente, privatizar as empresas localizadas em setores que representavam a base da estrutura industrial, como: a siderurgia, a petroquímica e a produção de fertilizantes. A privatização desses setores possibilitaria o aumento da eficiência administrativa e produtiva e a realização de novos investimentos.

Os objetivos gerais do PND, como exposto na Lei 8.031, de 12 de Abril de 1990 (em anexo), eram: 
I- reordenar a posição estratégica do Estado na economia, transferindo à iniciativa privada atividades indevidamente exploradas pelo setor público;

II- $\quad$ contribuir para a redução da dívida pública, concorrendo para o saneamento das finanças do setor público;

III- $\quad$ permitir a retomada de investimentos nas empresas e atividades que vierem a ser transferidas à iniciativa privada;

IV- contribuir para a modernização do parque industrial do País, ampliando sua competitividade e reforçando a capacidade empresarial nos diversos setores da economia;

V- contribuir para o fortalecimento do mercado de capitais, através do acréscimo da oferta de valores mobiliários e da democratização da propriedade de capital das empresas que integrarem o Programa.

O PND analisou o processo de industrialização brasileira. A análise do Governo Collor constatou que houve no Brasil a construção de um parque produtivo diversificado e integrado, num período relativamente curto, por meio de uma proteção indiscriminada e concessão abusiva de subsídios, resultando em um quadro subseqüente de estagnação da produtividade nos anos 1980. Nesse entendimento, propunha-se a reestruturação econômica via o forte dinamismo da iniciativa privada, cabendo ao Estado suplementar a atuação do setor privado com a criação de condições macroeconômicas, infra-estruturais e institucionais.

Conhecidas as intenções do Programa Nacional de Desestatização, parte do Projeto de Governo do Presidente Collor, convém verificar os resultados alcançados.

Collor expandiu o programa de privatizações esboçado por Figueiredo e Sarney. A partir do Governo Collor, não se fala mais em atividades vinculadas à segurança nacional, nem em responsabilidade pela infra-estrutura básica do país. A idéia era transferir à iniciativa privada todas as atividades econômicas onde a presença do Estado não era insubstituível.

O Governo Collor deu início à venda de empresas cuja propriedade sempre foi do setor público, respeitados os monopólios constitucionais. Primeiramente, as empresas que 
haviam sido estatizadas por dívidas foram devolvidas ao setor privado. Posteriormente, foram privatizadas empresas do setor siderúrgico e petroquímico.

As privatizações eram aceitas pela maior parte da sociedade civil, pela mídia e tinham o apoio de grandes empresários. O maior problema que o governo enfrentava era a questão inflacionária, pois, nenhum de seus planos de estabilização econômica apresentou sucesso. Os Planos Collor I e Collor II falharam e mesmo as políticas que não eram contestadas - políticas de abertura comercial e privatização - tinham poucos e custosos resultados. Tornou-se impossível para o Governo conter a inflação e conciliar as forças políticas que traziam revelações e acusações de corrupção, o que findou, no segundo semestre de 1992, no impeachment de Collor. (CALDAS e PEIXOTO, 2001, p. 117 e 118).

\subsection{Reformas Econômicas no Governo Itamar}

Com a saída de Collor, Itamar Franco assumiu o poder e manteve o programa de privatizações juntamente com o programa de liberalização comercial. Embora Itamar Franco tenha se mostrado sempre crítico ao processo de privatização, como Vicepresidente e durante o período de afastamento de Collor, passou a não se opor a este processo. Entretanto, defendia que deveria caber ao Congresso Nacional, caso a caso, a decisão de se transferir uma empresa estatal ao setor privado. (AMARAL FILHO, 1996, p.140).

Antes do governo Itamar havia um clima de desconfiança e dificuldades econômicas. Ambiciosos planos econômicos haviam sido lançados, muitos deles ao "arrepio da Lei”. O Governo Itamar Franco foi quem conseguiu lograr êxito no combate à inflação após doze planos de estabilização econômica, que ocorreram entre 1979 e 1992, quando foi lançado 
o Plano Real, sendo então Ministro da Fazenda Fernando Henrique Cardoso. (LONGO, 1993, p. 37).

No período do Governo Itamar Franco (1993-94) mais de quinze grandes empresas de diferentes setores foram privatizadas, entre elas pode-se citar: Goiásfértil (produção de fertilizantes), Acesita (siderurgia), Companhia Brasileira de Estireno - CBE (petroquímica), entre outras. O Governo precisava da aprovação da Lei de Concessão para poder ampliar a relação de empresas a serem vendidas. Ainda no Governo Itamar o monopólio das telecomunicações, cuja quebra dependia de alterações do texto constitucional, passou a ser criticado por diversos setores, alegando-se que o mesmo teria provocado atraso tecnológico e desinvestimento. (AMARAL FILHO, 1996, p.140).

O que ocorreu nos períodos de Collor e Itamar foi uma tomada de posição orientada a combater a crise brasileira dos anos 80. É importante ressaltar que foi o presidente Collor quem deu início às principais reformas neoliberais, entre elas, destacam-se: privatização, desregulamentação da economia, redução tarifária, quebra do monopólio estatal em setores estratégicos da economia, maior liberdade de atuação do capital estrangeiro, enfim, a abertura econômica do Brasil ao exterior. (CALDAS e PEIXOTO, 2001, p. 141).

\subsection{Reformas Econômicas no Primeiro Governo FHC}

Ao assumir a Presidência da República, Fernando Henrique Cardoso antecipou a natureza que esperava para seu Governo. Essa ia à direção de superar a Era Vargas e seu modelo de Estado intervencionista. Todavia, havia uma pergunta automática que não teve uma resposta tão clara: afinal, o que se desejava construir alternativamente diante da percepção do esgotamento da Era Vargas? (BARBOSA FILHO, 1996, p.20). 
Parte da resposta a essa pergunta é o que pretendo apresentar neste tópico, delimitado, contudo, ao estudo de um aspecto dessa realidade, o da privatização das telecomunicações.

Algumas avaliações apressadas poderiam sugerir que as reformas operadas ao longo dos anos 1990 foram uma simples substituição do Estado pelo mercado. Não é possível dizer que o Estado teve sua capacidade de intervenção destruída, mas sua lógica de atuação se direcionou à abertura econômica e a um redimensionamento. (DINIZ e BOSCHI, 2002, p.3).

No Brasil, o liberalismo político e econômico nunca foi o principal provedor do desenvolvimento. Ao contrário, o país aumentou e diversificou seu parque industrial por meio do apoio estatal à indústria doméstica. Contudo, como já bastante enfatizado, as transformações e insucessos da década de 1980 foram uma das principais justificativas adotadas pelo governo para a adoção de um modelo menos intervencionista e mais regulador. Todavia, não havia ainda no Estado brasileiro do final da década de 1980 e início da década de 1990, meios bem definidos e reformas do texto constitucional que fossem claras quanto aos limites e fronteiras da atuação do Estado.

A Constituição de 1988 de um lado assegurava os princípios da livre concorrência e da iniciativa privada como forma de organização econômica, e, por outro lado, inseria o nacionalismo econômico estatizante em vários de seus artigos, particularmente no tocante a alguns monopólios. (CALDAS e PEIXOTO, 2001, p. 143).

O texto constitucional foi significativamente alterado a partir do primeiro Governo FHC e setores estratégicos da economia, como o setor das telecomunicações, considerado monopólio estatal, passou a operar em regime de concessão. Alguns autores, como Licínio Velasco Júnior, afirmam que o Governo Fernando Henrique Cardoso trouxe uma nova fase na questão das privatizações, pois, na chamada $1^{\mathrm{a}}$ fase - Sarney, Collor e Itamar - o 
Estado abandona funções empresariais em prol de maior eficiência do setor privado nessas funções. Já no Governo FHC, as privatizações alcançam os serviços públicos e o Estado passa a ser o responsável pelas atividades de regulação e fiscalização. (VELASCO, 1997, p. 5).

A modernização do Estado, a manutenção da precedente abertura comercial e financeira aos capitais estrangeiros, associada à sustentabilidade do plano de estabilização econômica, foi a base da plataforma que elegeu FHC. O período deu início a uma nova fase do PND, em que o Programa foi ampliado, por meio da Lei 9.491, de 9 de setembro de 1997 (em anexo), que revogou a Lei que dera início ao programa ainda durante o Governo Collor.

Algumas alterações necessárias para ampliar o programa de privatização dependiam ainda de alterações constitucionais. Foi necessário reforçar a governança, a fim de conseguir importantes mudanças no texto constitucional. A Constituição de 1988 privilegiou o capitalismo de Estado em detrimento do de mercado. Para que o Brasil se ajustasse à nova era da globalização, tornou-se necessária uma profunda alteração no capítulo que tratava da Ordem Econômica da Carta.

Seis pontos podem ser considerados importantes nas alterações propostas no texto constitucional:

1- Monopólio estatal das telecomunicações;

2- Monopólio estatal do petróleo;

3- Redefinição do conceito de empresa nacional;

4- Participação das empresas estrangeiras no setor de mineração;

5- A navegação de cabotagem;

6- A comercialização de gás canalizado. 
Como afirmam Antônio Carlos Pojo do Rego e João Paulo Peixoto: "Estes temas, quando aprovados, levaram a uma efetiva liberalização econômica; atingindo parte fundamental da reforma do Estado". (PEIXOTO e POJO DO REGO, 1998, p. 124 e 125).

Segundo o ministro Bresser Pereira, responsável pelo PND de FHC, o novo papel do Estado é de facilitador para que a economia se torne internacionalmente competitiva e, ao conceder serviços públicos ao setor privado, o Estado se dedicará mais às atividades de regulação e fiscalização desses serviços e a intervenção será no campo da educação, saúde, cultura, desenvolvimento tecnológico e infra-estrutura. (PEREIRA, 1996, p. 1).

No Governo FHC, foi criado o Conselho Nacional de Desestatização (CAD) com o objetivo de agilizar o processo de tomada de decisão de privatizações. O CAD era integrado por ministros e diretamente subordinado ao Presidente da República. Buscavase a parceria do setor privado para superar a intervenção estatal nos setores de energia elétrica, transportes e telecomunicações. Como nos fala José Serra, então ministro do planejamento (1995, p. 2).

Ao conceder serviços públicos ao setor privado, o Estado poderá dedicar-se mais adequadamente e exclusivamente às atividades de regulação e fiscalização desses serviços, tarefas essenciais para o desenvolvimento econômico e social do País. A consolidação do marco regulatório permitirá aos investidores regras claras e segurança para sua tomada de decisão e garantirá a qualidade e continuidade dos serviços prestados à população.

Embora o PND tenha sido iniciado no Governo Collor, sua continuidade foi viabilizada e ampliada nos governos posteriores, devido à determinação de acabar com os monopólios do setor público em infra-estrutura e pela estabilização e força política que o Plano Real trouxe, o que possibilitou as emendas constitucionais necessárias para quebrar os monopólios estatais. 
A criação das empresas estatais esteve associada ao nacionalismo e à falhas regulatórias; as principais preocupações estavam relacionadas com o desenvolvimentismo - criação de um setor industrial diversificado no Brasil; preocupação com a segurança nacional; desejo de manter as indústrias estratégicas sob o controle do Governo; substituição de importações e estatização de empresas falidas. A privatização, por sua vez, esteve associada à idéia de estabilização econômica, redução da dívida pública, maior eficiência do setor privado e necessidade de expansão dos investimentos. O então presidente Fernando Henrique Cardoso assinala que a política de privatização é conseqüência da internacionalização da produção, da pressão avassaladora dos mercados competitivos e também da crise fiscal do Estado contemporâneo. (CARDOSO, 1998, p. 7).

O Primeiro Governo FHC, como já ressaltado, enfatizara principalmente as reformas estruturais. Um dos maiores exemplos do período e objeto deste trabalho foi o setor das telecomunicações, que, por meio da Proposta de Emenda à Constituição No 03 de 1995, aprovada no dia 15 de agosto do mesmo ano, teve seu monopólio quebrado. O texto constitucional foi alterado, criando a Emenda Constitucional №. 8 de 1995. 


\section{Privatização das Telecomunicações: Contexto, Capacidade e Interesse do Estado Brasileiro}

\subsection{Breve Histórico das Telecomunicações no Brasil}

A invenção do telefone ocorreu nos Estados Unidos, em 1875, pelo escocês Alexandre Graham Bell. Poucos anos depois o feito já havia chegado ao Brasil, mais precisamente, em 1877, sob o governo do Imperador D. Pedro II, época em que as primeiras linhas telefônicas foram instaladas. (TEIXEIRA e TOYSHIMA, 2003, p.152).

Em 1881 a primeira concessão do serviço de telefonia foi dada à empresa Telephone Company. A partir de 1882, várias concessões de telefonia foram outorgadas nas principais cidades brasileiras. A regulação do setor aconteceu por meio do Decreto $\mathrm{n}^{\circ}$ 8.453-A, de 11 de março de 1882 , que estabelecia a base para a concessão de linhas no país. (BASTO, 1988, p.2).

Como exemplo de empresas que passaram a atuar no Brasil com fins comercias podese citar a empresa alemã Brasilianische Elektricitats Geseleschaft e a empresa canadense Canadense Brazilian Traction Light \& Power. Nesse período, que se estendeu de 1912 até o início da Segunda Guerra Mundial, vários telefones foram instalados no país. Já nos anos da guerra houve uma certa paralisia no setor. (TEIXEIRA e TOYSHIMA, 2003, p.152).

A Constituição de 1946 previa que os serviços públicos de telecomunicações deveriam ser explorados diretamente pelos governos estaduais e/ou municipais, ou por meio de concessões. Uma vez que poucos estados e municípios exerceram a função de exploração de telefonia prevaleceu o sistema de concessões. Miranda (1955, p. 50) fala que esse 
período trouxe consigo uma grande falta de controle governamental no setor: "As redes telefônicas espalham-se pelo Brasil afora, sem qualquer orientação superior, pelo menos coordenadora”.

No ano de 1962, o país possuía pouco mais de 1 milhão de linhas telefônicas e mais de 900 concessionárias de serviços telefônicos atuando no país. Sobre este aspecto convém ressaltar o trecho de Teixeira e Toyshima (2003, p. 153).

\begin{abstract}
A grande diversificação de empresas concessionárias implicava a coexistência de uma grande variedade de equipamentos utilizados para operar o sistema de telefonia, o que consistia num entrave à padronização e interligação das diversas áreas do país, já que um equipamento utilizado por uma empresa poderia ser, até certo ponto, incompatível com o de outra empresa, dificultando a interligação entre os sistemas. Tal situação levava a um maior número de chamadas interrompidas ou não completadas, acarretando maior custo econômico e social para os usuários do sistema.
\end{abstract}

Os entraves acarretados pela grande diversidade de empresas que operavam no país levavam a um cenário de fragmentação, de diferentes padrões técnicos de operação, de métodos administrativos variados e de mau funcionamento do setor, o que impedia a atuação do governo no sentido de propor uma política específica que fosse capaz de incentivar novos investimentos, promover a expansão e corrigir as falhas do sistema. Deve-se lembrar ainda que as regiões menos populosas do Brasil eram pouco beneficiadas com o serviço de telefonia, pois, as empresas concentravam seus serviços nas regiões com maior população. (TEIXEIRA E TOYSHIMA, 2003, p. 153).

Esses fatores associados à importância estratégica e de segurança nacional que o período militar atribuiu ao setor de telecomunicações fizeram com que houvesse uma mudança na forma e no processo de conduzir a execução do serviço. 


\subsection{Modelo Intervencionista das Telecomunicações no Brasil}

Na segunda metade do Século XX, o setor das telecomunicações passou por inúmeras e significativas transformações estruturais. A fase inicial desse período destacou-se pela intervenção estatal, justificada pela relevância estratégica do setor.

A intervenção estatal veio como uma das conseqüências da forma como o setor fora conduzido até o fim dos anos 50, pois, como enfatizado anteriormente, a exploração do serviço de telefonia no Brasil ocorria de forma desordenada, sem padronização e sem interconexão. Eram quase mil companhias telefônicas que operavam no país, o que significava uma alta fragmentação e baixa qualidade dos serviços prestados. Com a desarticulação operacional e administrativa das concessionárias este modelo privado degradou-se progressivamente e acabou por fracassar. (NEVES, 2002, p. 2).

Em 1962, sob a bandeira da importância estratégica para a integração e o desenvolvimento nacional, o setor das telecomunicações teve sua prestação de serviço disciplinada. A Lei 4.117, de 27 de agosto de 1962, instituiu o Código Brasileiro de Telecomunicações e colocou o serviço sob o controle de uma autoridade federal -

Conselho Nacional de Telecomunicações (Contel) - subordinado diretamente à Presidência da República. (NEVES, 2002, p. 2).

A estatização das telecomunicações foi uma ação motivada não apenas pelo "modismo ideológico" de intervenção econômica para o desenvolvimento, que estava em andamento em vários campos da política econômica no Brasil e no mundo, mas foi também motivada por razões de segurança nacional, somada ainda ao fracasso da política nacional de concessões às empresas estrangeiras. (VIANNA, 1993, p.46). 
A nova política pública do setor de telecomunicações integrou as companhias em funcionamento, por meio do Sistema Nacional de Telecomunicações (SNT), autorizou a criação da Empresa Brasileira de Telecomunicações (Embratel) e criou o Fundo Nacional de Telecomunicações (FNT).

A década de 1960, portanto, manteve a característica da atuação governamental em vigência, ou seja, destacou-se na institucionalização, fiscalização, estatização, centralização e integração dos serviços prestados na telefonia nacional. (NEVES, 2002, p. 3).

A política governamental iniciada em 1962 teve continuidade na década de 1970, com a criação, em 1972, da Telebrás. A Telebrás significou quase um monopólio do setor, em que pese que a maioria das companhias foi absorvida pela estatal, restando apenas poucas companhias privadas em lugares considerados menos estratégicos no país. (NEVES, 2002, p. 4).

A nova prestadora estatal era vinculada ao Ministério das Telecomunicações. É possível dizer que a criação da Telebrás representou um progresso nos serviços de telecomunicações do país, mas a estatal não teve muitos anos de êxito, pois, inúmeras mudanças ocorridas na década de 1980 afetaram sua estrutura.

Como mostrado no capítulo anterior, o Brasil chegou à década de 1980 com um modelo de Estado altamente intervencionista. A presença das empresas estatais em quase todos os setores da atividade econômica foi fruto dessa política. Todavia, a instabilidade econômica que o país enfrentou nos anos 1980 foi um dos fatores que levaram a uma nova política de abertura econômica e privatizações. Essas crises internas já recorrentes e o processo de globalização e internacionalização econômica, produtiva e tecnológica aceleraram de maneira intensa o processo de privatização, que, por sua vez, atingiu o sistema de telecomunicações. 
Nos anos 80 , porém, as modificações no cenário político e a piora da situação econômico-social do país reverteram o ritmo acelerado de desenvolvimento do setor. A partir daquela década, os reajustes de tarifa inferiores à inflação, a implantação de subsídios cruzados nos produtos, a politização dos cargos executivos das estatais a as restrições impostas pelo governo federal ao uso do FNT e do lucro operacional da Telebrás reduziram a capacidade de investir e, ao longo do tempo, tiveram como conseqüência a formação de vultosa demanda reprimida, apontando sinais de esgotamento do modelo monopolista estatal. (NEVES, 2002, p. 5).

Mesmo nesse cenário, as telecomunicações conseguiram um avanço tecnológico considerável. Em 1985 e 1986 foram lançados satélites que permitiram a integração do território brasileiro e iniciou-se a implantação da telefonia móvel. Contudo, houve a escassez de novas linhas, aumento das tarifas e congestionamento do serviço. Em relação aos recursos, as restrições impostas pelo governo federal e limitações nos financiamentos contribuíram para a falta de verbas. Para tentar viabilizar o financiamento do setor, os consumidores eram estimulados a comprar ações da Telebrás ou de suas subsidiárias. (NEVES, 2002, p. 5).

\subsection{Endividamento e Esgotamento do Modelo Estatal}

A privatização, em seu sentido mais básico, é a transferência dos ativos da esfera pública para a esfera privada da economia em busca de ganhos de eficiência; estes podem ocorrer, desde que a desregulamentação não traga empresas que busquem estabelecer o domínio em alguma parte do mercado. (CAVALCANTI, 1994, p. 99).

José Carlos Cavalcanti explora melhor essa questão como no trecho que segue: 
Durante muitos anos economistas e outros cientistas sociais entenderam que em certas atividades econômicas a 'mão invisível do mercado', como uma vez reconhecida por Adam Smith, poderia não conduzir a uma alocação de recursos de um modo socialmente desejado. Daí, então, a necessidade da interferência do governo na superação de 'falhas nos mercados'. [...] É fato reconhecido que os mercados podem falhar. A grande mudança recente é que agora também se reconhece que pode haver falha do governo [...] O foco de atenção dessa postura crítica tem se dirigido de modo particular à expansão das empresas públicas, ou estatais, as quais representam uma parte significante da produção e do investimento em inúmeros países, fundamentalmente naqueles em desenvolvimento, como é reconhecido internacionalmente o Brasil. Essas empresas foram vistas pelos governos passados como um importante instrumento de fomento de rápido progresso técnico e mudanças. [...] Em muitos países, no entanto, a contribuição dessas empresas para o processo de desenvolvimento não tem correspondido às expectativas. Criadas na expectativa de gerar superávits para os governos, que por sua vez seriam reinvestidos, essas empresas (salvo honrosas exceções) têm demandado massivos subsídios, impondo uma excessiva carga fiscal à economia. Fundamentalmente, por essa razão, tem havido uma crescente preocupação com a performance econômica dessas empresas, e isso tem levado, além de outras considerações, à emergência das hoje famosas 'políticas de privatização'. (CAVALCANTI, 1994, P. 100).

No Brasil, a questão de enxugamento da máquina estatal era aceita, não só pelo fato de serem muitas as empresas desse tipo, mas também por se considerar as estatais uma das principais responsáveis pela inflação brasileira e pelo déficit público. Dessa forma, a maior parte da sociedade recebia bem os programas de privatização dos governos posteriores a Figueiredo (1979).

Conquanto houvesse esse apoio geral às privatizações, a dinâmica operacional do sistema de telefonia demandou maiores atenções. Na maior parte dos países capitalistas ocidentais o sistema de telefonia foi por muitos anos um monopólio. A razão dessa opção pelo monopólio do Estado foi, segundo Feldmann, uma forma de democratizar o acesso ao sistema, pois, se o sistema fosse aberto à livre concorrência, seria lógico que as empresas fornecedoras de serviço, procurando maximizar seus lucros, oferecessem seus serviços apenas a quem pudesse pagar. Ou seja, boa parte da população pobre do país não teria como acessar o serviço. (FELDMANN, 1991, p.3).

Para os defensores da desregulamentação no setor das telecomunicações, o argumento era de que haveria competição quando diferentes empresas entrassem na briga pela participação relativa no mercado, e isso significaria melhora na qualidade dos serviços 
prestados e diminuição das tarifas, bem diferente do que o Brasil tinha experimentado quando teve um sistema de telecomunicações privado. Mas havia também, segundo Stiglitz, uma forte crença na idéia da "vantagem do primeiro a entrar", a possibilidade de que a primeira empresa em um mercado particular poderia dominar (winner takes all), dessa forma, empresas gastariam muito para certificarem-se de seu domínio. Assim a política de desregulamentação no setor das telecomunicações não estava preocupada apenas com a produção de melhores produtos, como seus proponentes sustentam, mas buscava-se estabelecer o domínio em alguma parte do mercado. (STIGLITZ, 2003, p. 116).

O Brasil foi um dos países do Terceiro Mundo que mais avançou no setor de telecomunicações nos anos 1970. Feldmann aponta como algo intrigante a comparação dos números desta década com os números da década de 1980, pois, nos governos Figueiredo (1979 - 1984) e Sarney (1985 - 1990) houve uma nítida intenção de desmantelar o modelo brasileiro de telecomunicações, talvez com o intuito de se demonstrar que esse tipo de modelo - estatal - não podia ser eficiente. (FELDMANN, 1991, p. 3).

Já para Gilberto Geraldo Garbi (1991, p. 3), o desmantelamento que ocorreu no setor das telecomunicações depois da década de 1980 não foi intencional:

\footnotetext{
Mera e triste conseqüência da intromissão governamental e política em uma atividade que até então, servia de exemplo ao mundo em desenvolvimento [...] $\mathrm{O}$ retrocesso vivido por nossas telecomunicações foi mera decorrência inescapável de serem elas estatais do Terceiro Mundo.
}

Depois da criação da Embratel, em 1965, época em que o Governo se deu conta da impossibilidade de desenvolver o país sem telecomunicações, foram feitos investimentos 
expressivos no setor. Contudo, já em 1970, esses recursos foram retirados do setor, levando a um significativo retrocesso na década de 1980.

Entre 1978 e 1989 os investimentos do governo federal caíram 72\%, passando de 1,4\% do PIB para apenas 0,4\%. (FELDMANN, 1991, p. 3).

\begin{abstract}
Ante tais condições, o setor foi obrigado a estruturar no mecanismo de autofinanciamento sua necessidade de expansão. Conforme relatado, os novos assinantes, ao encomendarem a linha telefônica, eram compelidos a comprar ações da Telebrás ou de suas subsidiárias, sendo o serviço, em geral, disponibilizado em um ou dois anos após a inscrição. Com isso, por estar sendo transferido ao usuário o 'encargo' dos investimentos, os valores pagos por novas linhas eram elevados demais. Tal fato, aliado à conjuntura econômica do país, reduziu o montante de recursos destinados aos planos de expansão, não sendo estes suficientes nem sequer para financiar a demanda reprimida de linhas telefônicas [...] No Brasil, a primeira metade da década de 90, o evidente esgotamento do modelo e as dificuldades de financiar o setor, endossaram a necessidade de rever a estrutura prevista para as telecomunicações. (NEVES, p. 6).
\end{abstract}

Segundo César Benjamin, a demanda reprimida por telefonia foi o principal elemento do processo de privatização. No entanto, a demanda reprimida foi conseqüência da proibição de investimentos da antiga Telebrás, feitas por sucessivos governos. (BENJAMIN e RIBEIRO, 2004, p. 1).

Para entender melhor a questão da demanda reprimida por telefonia no Brasil é necessário observar que, no histórico das telecomunicações, em 1972 - quando o setor passou para o controle estatal - havia, em média, 1 telefone para cada 100 habitantes. De 1972 a 1993 o índice de telefonia aumentou para 8,4 telefones para cada 100 habitantes.

Esses dados revelam que a Telebrás conseguiu aumentar o acesso à telefonia no Brasil. Contudo, outros países já apresentavam números bem mais significativos; como a Suíça que tinha 70,32 telefones para cada cem habitantes, os Estados Unidos com 58,57, a 
Alemanha com 43,11, ou mesmo a Argentina com 11,17. O Brasil nesse ranking ocupava apenas o $42^{\circ}$ lugar. (SIQUEIRA, 1993, p. 25).

Pinheiro (1994, p. 48) ressalta que os dados de distribuição de renda e renda per capita devem ser analisados pois as camadas de baixo poder aquisitivo tendem a ter suas preferências centradas em subsistência ou, em outras palavras, em alimentação, saúde e educação, em detrimento ao acesso à telefonia.

Os dados de concentração de renda ajudam a entender melhor os argumentos do autor, pois, até 1994, em cada 100 habitantes apenas 8 tinham algum aparelho de telefone. Todavia, dentre os 137 milhões que ainda não possuíam telefone, 33,7 milhões viviam em situação de pobreza absoluta; outros 39,2 milhões viviam com um salário mínimo e todos esses e ainda crianças contavam nas estatísticas de demanda por telefonia. (VIANNA, 1994, p. 55).

Embora existam esses e outros argumentos que expliquem os fatores que levaram a um acesso limitado às telecomunicações no Brasil, esse argumento foi bastante utilizado pelos defensores da desestatização do setor.

O sistema de telecomunicações enfrentava vários outros problemas que levavam ao seu endividamento e esgotamento. É possível dizer que o modelo de monopólio estatal funcionou bem nos primeiros dez anos de Telebrás. Foi quando o Brasil implantou a rede básica da Embratel, organizou o Ministério das Telecomunicações e construiu um sistema de grande porte ao longo dos anos 1970.

No entanto, a partir da década de 1980, o governo além de reduzir a prioridade dos investimentos no setor, passou a corrigir as tarifas locais abaixo dos índices de inflação, descapitalizando as empresas e reduzindo sua capacidade de investimento. Esse sistema de subsídios era complexo, por exemplo, a chamada local era inferior ao seu custo de produção, o que era compensado pelas tarifas das chamadas interurbanas. Houve ainda o 
confisco dos recursos do FNT e dos superávits das operadoras do Sistema Telebrás. (SIQUEIRA e MANCINI, 1993, p. 10).

Além disso, podem-se citar os reflexos da crise econômico-financeira vivida pelo país, que afetaram o setor, particularmente para obter empréstimos.

\subsection{Privatização das Telecomunicações: Atuação do Congresso Nacional e Instrumentos}

\section{Legais}

O monopólio estatal das telecomunicações estava definido no Artigo 21, XI, da Constituição Federal. Segundo esse artigo, compete à União explorar, diretamente ou mediante concessão a empresas sob controle acionário estatal, os serviços telefônicos, telegráficos, de transmissão de dados e demais serviços públicos de telecomunicações, assegurada a prestação de serviços de informações por entidade de direito privado, através da rede pública de telecomunicações explorada pela União. (PEIXOTO e POJO DO REGO, 1994, p. 142).

Com esse texto constitucional de 1988 o governo tinha permissão para atuar de forma monopolística. O texto constitucional que trata da ordem econômica, fazia saber que o Brasil não abriria seu mercado de telecomunicações à iniciativa privada, a menos que se fizessem as modificações necessárias na Carta Magna.

Durante o período de revisão constitucional - 1993 - 68\% dos parlamentares se posicionavam a favor de alterações no texto constitucional e $34 \%$ se posicionavam a favor da privatização das telecomunicações. (PEIXOTO e POJO DO REGO, 1994, p. 143).

Os partidos políticos que se posicionavam contra o processo de revisão constitucional, mais especificamente, contra a quebra dos monopólios estatais, eram: Partido dos Trabalhadores (PT) e o Partido Democrático Trabalhista (PDT), além de outros partidos 
de esquerda, como o Partido Socialista Brasileiro (PSB) e o Partido Comunista do Brasil (PC do B). Dentre esses partidos, o PDT era considerado o mais radical, pois, afirmava que as reformas eram apenas um golpe disfarçado em nome dos interesses do capital estrangeiro e dos grupos privados nacionais. (PEIXOTO e POJO DO REGO, 1994, p. 148).

Por outro lado, havia o Partido da Frente Liberal (PFL) que fez a mais consistente defesa do processo de revisão constitucional. O Partido propunha a redução do papel do Estado na atividade econômica e a redução do monopólio estatal.

A Tabela 1 descreve, de forma resumida, as declarações feitas no período por alguns dos principais partidos políticos brasileiros a respeito do processo de privatização das telecomunicações, outros partidos se manifestavam de forma mais direta ao processo de revisão constitucional em geral e por isso não constam na tabela abaixo:

Tabela 1: Posicionamento dos principais Partidos Políticos quanto ao monopólio estatal das Telecomunicações

\begin{tabular}{|l|l|}
\hline \multicolumn{1}{|c|}{ Monopólio das Telecomunicações. } & Partido \\
\hline Manutenção do monopólio estatal. & PT \\
\hline Elimina a exigência de controle estatal, possibilitando a transferência do & PSDB \\
controle acionário para a iniciativa privada. & \\
\hline Extingue o monopólio estatal e permite empresas privadas prestarem serviços & PFL \\
de telecomunicações mediante outorga. & \\
\hline Quebra do monopólio, permitindo a exploração do serviço por empresas & PPR \\
privadas, mediante concessão. & \\
\hline
\end{tabular}

(PEIXOTO e POJO DO REGO, 1998, p. 132, adaptada aos propósitos deste trabalho). 
Embora a discussão da quebra do monopólio das telecomunicações tenha feito parte da revisão constitucional de 1993, foi a Proposta de Emenda à Constituição - PEC 03 de 1995 - que propôs a flexibilização da restrição que impunha à União Federal a exclusividade da exploração dos serviços públicos de telecomunicações, alterando, dessa forma, o inciso XI do artigo 21 da Constituição Federal e restringindo a competência do Estado à função de fiscalização.

A PEC tramitou de fevereiro de 1995 a agosto de 1995 na Câmara dos Deputados e no Senado Federal. Para uma melhor compreensão dos resultados das votações no primeiro e segundo turno de votações, que estão expostos nas tabelas abaixo, convém destacar que o número total de deputados da legislatura em análise (1995-1999) era de 513; e 81 era o número total de senadores nesse mesmo período.

Tabela 2: Resultado da votação da PEC 03/95 na Câmara

\begin{tabular}{|c|c|c|c|c|}
\hline $\mathbf{1}^{\mathbf{0}}$ Turno & Sim à Privatização & Não à Privatização & Abstenção & Total \\
\hline Resultado & 348 & 140 & 5 & 493 \\
\hline $\mathbf{2}^{\mathbf{0}}$ Turno & Sim à Privatização & Não à Privatização & Abstenção & Total \\
\hline Resultado & 357 & 136 & 5 & 498 \\
\hline
\end{tabular}

Fonte: http://www2.camara.gov.br/proposicoes 
Tabela 3: Posicionamento Partidário no Primeiro Turno de votação da Câmara

\begin{tabular}{|c|c|c|c|}
\hline PARTIDO & SIM & NÃO & ABSTENÇÃO \\
\hline PC do B & - & 10 & - \\
\hline PDT & 5 & 23 & 1 \\
\hline PFL & 87 & - & 1 \\
\hline PL & 11 & - & - \\
\hline PMDB & 78 & 27 & 1 \\
\hline PMN & 2 & 3 & - \\
\hline $\begin{array}{l}\mathbf{P P} \\
\end{array}$ & 27 & 3 & 1 \\
\hline PPR & 42 & 4 & - \\
\hline PPS & - & 2 & - \\
\hline PSB & 1 & 12 & - \\
\hline PSC & 2 & - & - \\
\hline PSD & 4 & - & - \\
\hline PSDB & 58 & 7 & - \\
\hline PT & - & 47 & - \\
\hline PTB & 27 & 3 & 1 \\
\hline PV & 1 & - & - \\
\hline Sem Partido & 2 & - & - \\
\hline
\end{tabular}


Tabela 4: Posicionamento Partidário no Segundo Turno de votação da Câmara

\begin{tabular}{|c|c|c|c|}
\hline PARTIDO & SIM & NÃO & ABSTENÇÃO \\
\hline PC do B & - & 10 & - \\
\hline PDT & 3 & 24 & 1 \\
\hline PFL & 90 & - & 1 \\
\hline PL & 12 & - & - \\
\hline PMDB & 72 & 26 & 2 \\
\hline PMN & 3 & 3 & - \\
\hline $\mathbf{P P}$ & 30 & 2 & 1 \\
\hline PPR & 43 & 3 & - \\
\hline PPS & - & 2 & - \\
\hline PSB & 2 & 11 & - \\
\hline PSC & 1 & - & - \\
\hline PSD & 4 & - & - \\
\hline PSDB & 66 & 5 & - \\
\hline PT & - & 48 & - \\
\hline PTB & 27 & 2 & - \\
\hline PV & 1 & - & - \\
\hline Sem Partido & 3 & - & - \\
\hline
\end{tabular}

Fonte: http://www2.camara.gov.br/proposicoes

A análise dos dados das tabelas 3 e 4 permite compreender um pouco mais do posicionamento político-ideológico dos partidos políticos em relação ao processo de privatização das telecomunicações. Nesse aspecto, destaca-se que, embora o comparecimento de deputados nas votações tenha sido bastante expressivo, não é possível 
desprezar a ausência de alguns parlamentares e assim ter uma idéia do posicionamento total dos deputados por bancada.

O primeiro ponto que convém enfatizar nos dados expostos é a continuidade do posicionamento adotado pelos parlamentares dos diversos partidos durante os dois turnos de votação da PEC. A migração de votos contrários para votos favoráveis, ou o inverso, foi praticamente inexistente. Da mesma forma, ocorreu com o número de abstenções, que pouco se alterou do primeiro para o segundo turno de votações.

$\mathrm{O}$ segundo ponto que pode ser colocado diz respeito à orientação e à coerência partidária na votação. Os partidos políticos tiveram um comportamento coerente ao esperado segundo posicionamento esquerda - direita. O PT, PDT, PC do B, PPS e PSB se mantiveram firmes em seu posicionamento contrário à privatização e foram unânimes ao votar contrário ao processo. A exceção foi o PSB, que no primeiro turno teve um voto favorável à privatização contra onze votos contrários e no segundo turno teve dois votos favoráveis ao processo de privatização contra onze votos contrários. Já os partidos de direita, como o PFL, PSDB e PPR deram um expressivo apoio à privatização. No caso do PFL, sua bancada foi unânime ao votar a favor. Já o PSDB e o PPR, embora não tenham apresentado uma unanimidade, tiveram a maioria de seus parlamentares votando favoravelmente. Os demais partidos; PL, PP, PSC, PSD, PTB e PV também não tiveram grandes dispersões em seu posicionamento e foram favoráveis à privatização das telecomunicações. Merecem destaque apenas o PMDB, que, embora tenha majoritariamente votado "sim" foi o partido que teve o número mais significante de parlamentares que votaram de forma dissensual e também o PMN que apresentou uma bancada praticamente dividida nos dois turnos de votação.

É possível deduzir que outras variáveis, como: o gênero, a região e a escolaridade dos parlamentares pouco influenciaram em seu posicionamento, uma vez que não é possível 
identificar, observando essas variáveis, formas confiáveis de se atribuir a elas as razões que influenciaram na votação.

No Senado Federal, os resultados do primeiro e segundo turno de votações se encontram na tabela abaixo:

Tabela 5: Resultado da votação da PEC 03/95 do Senado

\begin{tabular}{|c|c|c|c|c|}
\hline $\mathbf{1}^{\mathbf{0}}$ Turno & Sim à Privatização & Não à Privatização & Abstenção & Total \\
\hline Resultado & 62 & 12 & 0 & 74 \\
\hline $\mathbf{2}^{\mathbf{0}}$ Turno & Sim à Privatização & Não à Privatização & Abstenção & Total \\
\hline Resultado & 63 & 11 & 0 & 74 \\
\hline
\end{tabular}

Fonte: http://www.senado.gov.br/sf/atividade/Materia/

Tabela 6: Posicionamento Partidário no Primeiro Turno de votação do Senado

\begin{tabular}{|l|c|c|c|}
\hline PARTIDO & SIM & NÃO & ABSTENÇÃO \\
\hline PDT & 2 & 2 & - \\
\hline PFL & 20 & 1 & - \\
\hline PMDB & 15 & - & - \\
\hline PPB & 1 & 1 & - \\
\hline PPS & - & 1 & - \\
\hline PSB & 12 & - & - \\
\hline PSDB & - & 5 & - \\
\hline PT & 7 & - & - \\
\hline PTB & & & - \\
\hline
\end{tabular}

Fonte: http://www.senado.gov.br/sf/atividade/Materia/ 
Tabela 7: Posicionamento Partidário no Segundo Turno de votação do Senado

\begin{tabular}{|c|c|c|c|}
\hline PARTIDO & SIM & NÃO & ABSTENÇÃO \\
\hline PDT & 2 & 3 & - \\
\hline PFL & 20 & 1 & - \\
\hline PMDB & 16 & - & - \\
\hline PPB & 6 & 1 & - \\
\hline PPS & 1 & 2 & - \\
\hline PSB & - & - & - \\
\hline PSDB & 11 & 3 & - \\
\hline PT & - & - & - \\
\hline PTB & 7 & & - \\
\hline
\end{tabular}

Fonte: http://www.senado.gov.br/sf/atividade/Materia/

As tabelas 6 e 7 mostram o posicionamento partidário no Senado Federal. Assim como foi dito a respeito da análise feita das votações na Câmara, destaca-se aqui que, embora o comparecimento de senadores na votação tenha sido também bastante expressivo, não é possível desprezar a ausência de alguns deles e assim ter uma idéia do posicionamento total dos senadores por bancada.

É notável que não houve grandes mudanças no comportamento dos partidos entre os números da votação na Câmara com os números da votação no Senado. Fogem a essa regra, entretanto, o PDT, que no primeiro turno teve $50 \%$ de votos a favor e $50 \%$ de votos contra à privatização e no segundo turno se manteve próximo a esse número (bem diferente da unanimidade apresentada na Câmara) e também o PMDB que, ao contrário do que ocorreu no PDT, obteve uma dispersão no Senado inferior à da Câmara, tendo apenas 
$11 \%$ de votos contrários à privatização no primeiro turno e $6,0 \%$ de votos contrários no segundo turno de votações.

A aprovação pelo Congresso Nacional da PEC 3 de 1995, em 8 de agosto do mesmo ano, criou a Emenda Constitucional $\mathrm{N}^{\circ}$ 8/1995 e permitiu ao governo federal outorgar concessões para exploração de serviços de telecomunicações ao setor privado. A idéia se fundava na competição e na universalização dos serviços. Além de eliminar o monopólio estatal na prestação de serviços de telecomunicações, a Emenda determinou, ademais, a criação de um órgão regulador.

Foi a Lei 9.472, de 16 de julho de 1997, em anexo, que orientou a criação e funcionamento do órgão regulador das telecomunicações, fortalecendo o papel regulador do Estado e marcando o término da intervenção direta do Estado nas telecomunicações. Essa Lei, conhecida como Lei Geral das Telecomunicações (LGT) criou a Anatel. (CELLI JÚNIOR E SANTANA, 2004, p. 176).

\subsection{O Novo Modelo Adotado: A Quem Serviu?}

Com a Emenda Constitucional 8 de 1995 a Telebrás foi vendida e o território nacional foi dividido em áreas de outorga e os compradores, em sua maioria, foram consórcios liderados por empresas estrangeiras. (BENJAMIN, 2004, p. 1).

A partir do novo modelo adotado, houve, incontestavelmente, uma significativa expansão dos serviços de telecomunicações, o que não permite, contudo, afirmar que a expansão dos serviços foi conseqüência das privatizações, pois, conforme mostrado anteriormente, os recursos do FNT foram retirados significativamente no período que antecedeu a privatização, levando o sistema a uma intensa crise de recursos. Somente pouco antes da venda das ações da Telebrás o governo voltou a investir grande quantia de 
recursos a fim de valorizar o setor e aumentar o valor a ser arrecadado com a venda do mesmo. Como nos fala Aloysio Biondi (2003, p. 10 e 19).

\begin{abstract}
Antes de mais nada, é preciso relembrar um detalhe importante: antes das privatizações, o governo já havia começado a aumentar as tarifas alucinadamente, para assim garantir imensos lucros no futuro aos "compradores" - e sem que eles tivessem de enfrentar o risco de protestos e indignação do consumidor. Para as telefônicas, reajustes de até $500 \%$ a partir de 1995. [...]

Em 1996, o governo duplicou os investimentos nas teles, alcançando 7,5 bilhões de reais, chegou a 8,5 bilhões de reais em 1997 e investiu mais 5 bilhões de reais no primeiro semestre de 1998, totalizando, portanto, 21 bilhões de reais de investimento em dois anos e meio.
\end{abstract}

O episódio permite a reflexão sobre a inevitabilidade do esgotamento do setor, uma vez que em um curto espaço de tempo - que antecedeu a venda das ações da Telebrás - os investimentos feitos pelo governo no setor geraram grande lucro e sucesso nas telecomunicações.

Um dos motivos que estimularam o governo a empenhar-se em um programa de privatização foi a possibilidade de criar recursos para financiar o déficit público, buscavase também uma elevação da produtividade e da eficiência na prestação de serviços. Quanto aos possíveis efeitos negativos, pensava-se na possível redução das receitas do Estado. (LINS, 2000, p. 10).

Quanto à universalização dos serviços, os resultados sugerem uma elevação da produtividade e uma maior eficiência alocativa, mas sobre esse resultado convém ressaltar que foram aproveitados planos pré-existentes segundo as metas de universalização já previstas nos contratos de concessão. Já os recursos adquiridos com a venda foram transferidos ao Tesouro Nacional, sem a distinção dada aos mesmos, porém não há indicações que os recursos foram utilizados para fins sociais. (LINS, 2000, p. 19). 
No aspecto macroeconômico, constatou-se que os recursos aplicados ao pagamento da dívida pública foram insuficientes para que qualquer efeito positivo pudesse ser sentido, como nos fala Bernardo Estellita Lins (2000, p. 21): “Amadurece a percepção de que não houve ganhos com o processo: ficou um gosto de perda de soberania a troco de nada".

Por fim, pode-se salientar que o grande aumento de linhas disponíveis tanto em telefonia fixa quanto em telefonia móvel é apontado como um dos principais indicadores de êxito da transição. Contudo, esse aumento no número de linhas só refletiria uma universalização dos serviços se cada nova linha fosse comprada por quem não tinha nenhuma. Além disso, as operadoras só obtêm lucro se a rede for suficientemente densa, de modo que os ganhos superem os custos da prestação de serviço. Isso faz com que as grandes metrópoles tenham uma densidade muito maior no número de linhas telefônicas, em detrimento aos pequenos municípios e às zonas rurais. 


\section{Considerações Finais}

As várias mudanças estruturais ocorridas no cenário político brasileiro podem ser entendidas como parte de uma agenda permanente de reformas do Estado que envolvem a capacidade, o contexto e o interesse para que se permaneça com ou para que se modifique determinada forma de atuação estatal.

Os anos de 1930 trouxeram consigo esforços para modernizar a política e a economia brasileira. Nesse período a crença que prevalecia era de que o modelo liberal tinha entrado em declínio e o Estado, dessa forma, passou a assumir funções decisivas para o funcionamento e expansão econômica.

Essa idéia de fortalecimento do Estado e de suas atribuições desenvolvimentistas prevaleceu até meados da década de 1980. Já a partir de 1990, quando tiveram início as políticas de modernização do presidente Collor, o país voltou-se para a retirada e contenção da atuação estatal na economia.

Essa inspiração neoliberal, da última década do Século XX modificou o papel do Estado provedor para um Estado regulador, internalizando, assim, as principais diretrizes do Consenso de Washington e da economia globalizante.

A reforma do Estado no Brasil está, pois, associada às principais transformações do capitalismo mundial. As reformas de Fernando Collor e de Fernando Henrique Cardoso se inscreveram em um processo de mundialização e articulação da elite econômica e financeira brasileira, do poder do próprio Estado, do surgimento internacional do liberalismo econômico somado ao desejo de setores da sociedade para a superação de políticas tradicionais, o que acabou por legitimar as reformas implementadas no período.

O Governo Fernando Henrique Cardoso introduziu um marco de mudança constitucional no campo da atuação do Estado. Abriu-se um espaço maior para o capital 
estrangeiro e houve a quebra de monopólios em setores como: telecomunicações, petróleo, navegação de cabotagem, entre outros. A transferência dos monopólios estatais a empresas privadas acabou por tornar-se a característica central daquele governo.

A desnacionalização desses vários setores da economia muitas vezes assumiu a forma de uma construção inevitável e incontrolável, como se fosse um caminho único ao país. Isso atuava para legitimar perante a sociedade as ações de desestatização e reduzir conflitos de governabilidade.

Embora não se pretenda negar o enfraquecimento e esgotamento que a política econômica brasileira sofreu nos anos 1980, não é possível desconsiderar os aspectos de construção político-ideológico que foram frutos da ação política de sujeitos definidos, tais como: o governo, o empresariado, as grandes instituições financeiras e empresas multinacionais, que buscavam estabelecer uma hegemonia neoliberal.

A difusão desse ideal neoliberal, bem como da idéia de esgotamento das possibilidades do Estado intervir como provedor no campo econômico, durante as últimas décadas do século passado, levou a um sentimento de impotência e incapacidade de vários seguimentos da sociedade, trazendo a idéia de adaptação forçada ao contexto internacional.

O modelo do monopólio estatal das telecomunicações brasileiras foi desfeito sob o argumento de inevitabilidade do mercado como agente promotor de uma maior eficiência na alocação de recursos e desenvolvimento tecnológico em detrimento da capacidade empresarial do Estado.

Observa-se, entretanto, que o Estado, durante os anos em que monopolizou o setor, implementou inúmeras melhorias na telefonia e foi capaz de trazer unidade ao sistema que operava de maneira prejudicialmente fragmentada. Sabe-se que essas melhorias, ao final da década de 1980, entraram em colapso, quando o Estado passou a retirar recursos do 
FNT para transferi-los a outros setores e as políticas de subsídios cruzados (que buscavam beneficiar o usuário mais carente) muitas vezes não eram sustentáveis.

Contudo, nota-se que, pouco antes da privatização do setor, o reinvestimento estatal fez com que a retomada do crescimento se viabilizasse. Por seu turno, essa retomada do crescimento e expansão durou pouco sob a tutela do Estado, pois, logo em seguida, quebrou-se o monopólio e a Telebrás foi vendida.

Após a privatização o setor teve uma inegável melhoria e expansão dos serviços prestados, o que não pode ser exclusivamente atribuído ao novo modelo, uma vez que o antigo sofreu inúmeros desgastes políticos e financeiros que impediram sua expansão. A forma como o processo de privatização foi conduzido permite contestar a tão propalada incapacidade do Estado, pois, este pouco antes da venda, foi capaz de intervir e valorizar o setor.

Um outro ponto que merece destaque é a transferência da soma arrecadada com a venda das estatais para os setores como educação e saúde. Embora pouco possa se dizer sobre essa transferência, uma vez que não há dados claros e discriminados a esse respeito, é possível refletir que por duas vezes as telecomunicações serviram a esse fim e mesmo assim poucos resultados foram obtidos. Pois, além da venda ter tido esse destino a retirada de recursos do FNT tivera também essa finalidade. Outras questões como a politização dos cargos que a estatal possuía, vista como um grande empecilho para sua maior eficiência, pode também ser contrastada com a politização de hoje dos cargos das agências reguladoras.

Enfim, embora não seja possível esgotar as várias facetas do processo de privatização das telecomunicações no Brasil e nem, tampouco, tratar todos os fatores internos e externos que levaram à modificação do papel do Estado na economia, o que se pretendeu 
mostrar foi a importância da decisão e do posicionamento político na escolha do modelo adotado.

Pois, se é verdade que o país oscilou de 1930 a meados dos anos 1990 entre tendências de caráter de desenvolvimento nacionalista e de desenvolvimento associado ou capitalismo associado, não é possível desvincular isso dos partidos políticos e do Legislativo, mesmo porque isso poderia representar a desconsideração de que houve setores da sociedade que se posicionaram sobre o assunto, e o Congresso teve importante papel nesse sentido, uma vez que a quebra do monopólio foi ali decidida.

Por fim, a competição do país no cenário internacional não ficou tão evidente com as privatizações como ficou evidente a competição de empresas e setores internacionais no país. A efetividade da transferência do patrimônio estatal para empresas privadas foi uma reconstrução do Estado para ser capaz de novas formas de atuação, sem querer, com isso, retirar a importância de que os governos, grupos políticos e grupos econômicos tiveram nesse processo. A escolha política desses agentes, por tudo que foi mostrado, se sobrepõe ao argumento de sucateamento e esgotamento da Telebrás. 


\section{Referências Bibliográficas}

AMARAL, Marcos J.F. Privatização no Estado Contemporâneo. São Paulo, Ícone, 1996.

BARBOSA, Rubem F. Governo Fernando Henrique: Primeiro Ano. Seminário realizado no Instituto Universitário do Rio de Janeiro IUPERJ, Rio de Janeiro, 1996.

BASTO, José C. Perfil Institucional da Embratel. Brasília, 1988, 161 p. Dissertação (Mestrado em Administração). Departamento de Administração da Faculdade de Estudos Sociais Aplicados, Universidade de Brasília.

BENJAMIN, César; RIBEIRO, Rômulo T. Quadro Geral e Alternativas nas Telecomunicações Brasileiras. $2004 . \quad$ Disponível em <http://www.desempregozero.org.br $>$.

BIONDE, Aloysio. O Brasil privatizado: Um balanço do desmonte do Estado. São Paulo: Fundação Perseu Abramo, 2003.

BRASIL. Constituição (1988). Emenda Constitucional 08, de 15 agosto de 1995. Altera o inciso XI e a alínea "a” do inciso XII do Artigo 21 da Constituição Federal.

BRASIL. Congresso Nacional. Diário do Congresso Nacional. Votação Nominal da PEC 03 de 1995. Disponível em <http://www2.camara.gov.br/proposicoes〉. Acesso em $18 / 10 / 2005$.

BRASIL. Congresso Nacional. Votação Nominal da PEC 03 de 1995. Disponível em < https://www.senado.gov.br/sf/atividade/Materia >. Acesso em 18/10/2005.

BRUSSI, Antônio. Explorações na Análise da Semiperiferia: A Semiperiferia como um conceito político e econômico. Brasília: Cadernos de Ciência Política, 1988.

CALDAS, Ricardo W.; PEIXOTO, João Paulo M. Regimes Políticos, Eleições e Reformas Econômicas: de João Figueiredo a Fernando Henrique Cardoso. Brasília, Jurídica LTDA, 2001.

CARDOSO, Fernando H. Notas sobre a Reforma do Estado. Novos estudos CEBRAP, São Paulo, n. 50, p.5-12, mar.1998.

CAValCAnti, José C. O risco da Privatização das Telecomunicações no Brasil. Revista de Economia Política, vol. 14, nº 2 (54), p. 98-107, abril-junho 1994.

CELlI JÚNIOR, Umberto; SANTANA, Cláudia S. Telecomunicações no Brasil: Balanço e Perspectivas. Revista de Direito Mercantil - industrial, econômico e financeiro. Ano XLIII (nova Série). São Paulo, Malheiros. P. 175-186, 2004.

CHANG, Ha-Joon. Chutando a Escada. A Estratégia do Desenvolvimento em Perspectiva Histórica. São Paulo, UNESP, 2003. 
COLLOR, Fernando. Brasil: Um Projeto de Reconstrução Nacional. Brasília, 1990.

O Projeto de Reconstrução Nacional. (Discurso proferido por Sua Excelência o Senhor Fernando Collor, Presidente da República Federativa do Brasil, na Cerimônia de posse no Congresso Nacional). Brasília, 15 de março, 1990.

CRUZ, Verônica P. O Processo Decisório no Setor de Telecomunicações: a ANATEL e a escolha do padrão por TV Digital. Brasília, 2002, 106 p. Dissertação (Mestrado em Ciência Política). Departamento de Ciência Política, Universidade de Brasília.

DINIZ, Eli; BOSCHI, Renato R. Reformas Econômicas e Perspectivas do Capitalismo no Brasil dos Anos 90: Empresário, Democracia e Equidade. Trabalho a ser apresentado no $3^{\circ}$ Encontro Nacional da ABCP - Associação Brasileira de Ciência Política. Área: Economia e Política, Painel 1 A economia política da política econômica. UFF, Niterói, 31 de julho, 2002.

ETHEVALDO, Siqueira. Brasil, décimo na América Latina in SIQUEIRA, Ethevaldo (org). Telecomunicações Privatização ou Caos. São Paulo, Telepress, 1993, p. 24-40.

FELDMANN, Paulo, R. A Privatização das Telecomunicações. Folha de São Paulo, São Paulo, 04 de março de 1991. Caderno dinheiro, seção opinião econômica.

GARBI, Gilberto G. A Privatização das Telecomunicações. Folha de São Paulo, São Paulo, 30 de março de 1991. Caderno dinheiro, seção opinião econômica.

IANNI, Octávio. Estado e Planejamento Econômico no Brasil. Rio de Janeiro, Civilização Brasileira, 1979.

ISKANDAR, Jamil I. Normas da ABNT comentadas para Trabalhos Científicos. 2. ed. Curitiba: Juruá, 2003.

LINS, Bernardo E. Privatização das Telecomunicações Brasileiras: algumas lições. Caderno Aslegis, vol. 4, no 10, p.9 -25, janeiro abril, 2000.

LONGO, Carlos A. Políticas de Estabilização e Reforma Estrutural no Brasil. São Paulo, Centro de Estudos Konrad Adenauer - Stiffung, nº 2, 1993.

MIRANDA, Líbero. Os Serviços de Comunicações no Brasil. Rio de Janeiro: Departamento de Imprensa Nacional, 1955.

NEVES, Maurício S. O Setor das Telecomunicações. BNDES. Livro Setorial 13. In: Elizabeth Maria de São Paulo; Jorge Kalache Filho. (Org.). BNDES 50 Anos - Histórias Setoriais. 1 ed. São Paulo, 2002, v. 1, p. 297-319.

O’CONNOR, James. A Crise do Estado Capitalista. Rio de Janeiro, Paz e Terra, 1977.

PEIXOTO, João Paulo M.; POJO do REGO, Antonio C. A Revisão Constitucional e a Reforma do Estado Brasileiro. Revista de Administração pública, Rio de Janeiro, Fundação Getúlio Vargas, vol.28 nº 3, p. 133-154, julho-setembro, 1994. 
PEIXOTO, João Paulo M.; POJO do REGO, Antonio C. A Política das Reformas Econômicas no Brasil. Rio de janeiro, Expressão e Cultura, 1998.

PEIXOTO, João Paulo M. Statecraft: o legado do governo Fernando Henrique e os desafios de Lula. Brasília, 2003, mimeo.

PEREIRA, Bresser L.C. Da Administração Pública Burocrática à Gerencial. Revista do Serviço Público. Ano 47, v.120, n.1, jan-abr. 1996.

PINHEIRO, Stutz F. As telecomunicações e a "modernidade". In: Verdade Suada x Mentira Orquestrada. São Paulo: Paz e Terra, 1994, p. 47-49.

Constituições Brasileiras. Brasília, Senado federal, Centro de

Estudos Estratégicos e Escola de Administração Fazendária, 1999/2000.

REZENDE, Flávio da Cunha. Gastos Públicos e Mudanças Recentes no Papel do Estado Nacional. Novos Estudos CEBRAP, n. 62, março 2002, p. 123-139.

SERRA, José. A Nova Fase da Privatização. Programa Brasil em Ação, Brasíla, Presidência da República, Secretaria de Comunicação Social. Disponível em: < https://www.presidencia.gov.br/publi_04/COLECAO/fase1.htm>. Acesso em 28 set.2005.

SIQUEIRA, Ethevaldo; MANCINI, Luciana. Rumo ao caos. In: SIQUEIRA, Ethevaldo. Telecomunicações Privatização ou Caos. São Paulo: TelePres Editora LTDA, 1993, p.1023.

SOUZA, Juarez. Críticas à Construção de um Estado Neoliberal no Brasil (19872002: 15 Anos de Profundas Mudanças). Brasília, mimeo.

STIGLITZ, Joseph E. Os Exuberantes Anos 90. São Paulo, Companhia das Letras, 2003.

TEIXEIRA, Rogério de Assis; TOYSHIMA, Silvia Harumi. Evolução das Telecomunicações no Brasil: 1950 - 2001: o caso da telefonia. Revista Econômica do Nordeste, n.1, volume 34, jan-mar. 2003.

VELASCO, Licínio Jr. A Economia das Políticas Públicas: As Privatizações e a Reforma do Estado. BNDES, Textos para Discussão, nº 55, Rio de Janeiro, 1997.

VIANNA, Gaspar. Privatização das Telecomunicações. Rio de Janeiro, Notrya, 1993.

VIANNA, Gaspar L. Telecomunicações e Concentração de Renda. In BARROS, Jorge Pedro D. Telecomunicações: Verdade Suada x Mentira Orquestrada. Rio de Janeiro, Paz e Terra, 1994, p. 55-59.

Atrito em Washington. 17 de setembro de 1986. Disponível em: < http://vejaonline.abril.com.br/notia/servlet/newstorm.ns.presentation.NavigationServlet?p ublicationC...> Acesso em 13 jan.2006. 
Anexos

Anexo 1: Lei no 8.031, de 12 de abril de 1990.

Anexo 2: Lei no 9.491, de 9 de setembro de 1997.

Anexo 3: Lei no 9.472, de 16 de julho de 1997. 